\section{Interseeding Legumes into Chile: Legume Productivity and Effect on Chile Yield}

\author{
Steven J. Guldan ${ }^{1}$ and Charles A. Martin \\ Alcalde Sustainable Agriculture Science Center, New Mexico State University, \\ P.O. Box 159, Alcalde, NM 87511
}

\section{Jose Cueto-Wong ${ }^{2}$ and Robert L. Steiner ${ }^{3}$ \\ New Mexico State University, Las Cruces, NM 88003}

Additional index words. multiple cropping, relay intercropping, Vicia villosa, Medicago truncatula, Lens culinaris, Capsicum annuum, pepper

\begin{abstract}
Three legumes [hairy vetch (Vicia villosa Roth.), barrel medic (Medicago truncatula Gaerth.), and black lentil (Lens culinaris Medik.)] were interseeded into 'New Mexico 6-4' chile pepper (Capsicum annuum L.) when plants were $20-30 \mathrm{~cm}$ tall (3 Aug., "early" interseeding) or when plants were 30-40 cm tall (16-17 Aug., "late" interseeding) in 1993 and 1994. Our objectives were to determine the effect of legume interseeding on cumulative chile yield, and late-season dry-matter and nitrogen yields of aboveground portions of the legumes. Legumes were harvested on 8 Nov. 1993 and 15 Nov. 1994. Chile yield was not significantly affected by legume interseeding. In 1993, legumes accumulated $57 \%$ more dry matter and $55 \%$ more $N$ when interseeded 3 Aug. vs. 16 Aug. In 1994, legumes accumulated $91 \%$ more dry matter and $86 \%$ more $N$ when interseeded 3 Aug. vs. 17 Aug. Aboveground dry-matter yields in 1993 ranged from $1350 \mathrm{~kg} \cdot \mathrm{ha}^{-1}$ for black lentil interseeded late to $3370 \mathrm{~kg} \cdot \mathrm{ha}^{-1}$ for hairy vetch interseeded early. Nitrogen yields ranged from $52 \mathrm{~kg} \cdot \mathrm{ha}^{-1}$ for black lentil interseeded late to $136 \mathrm{~kg} \cdot \mathrm{ha} \mathrm{a}^{-1}$ for hairy vetch interseeded early. In 1994, hairy vetch was the highest yielding legume with dry matter at $1810 \mathrm{~kg}^{-h a^{-1}}$ and $N$ at $56 \mathrm{~kg}^{-h^{-1}}$ interseeded early, while black lentil yielded the lowest with dry matter at $504 \mathrm{~kg} \cdot \mathrm{ha}^{-1}$ and $\mathrm{N}$ at $17 \mathrm{~kg} \cdot \mathrm{ha}^{-1}$ interseeded late. In the spring following each interseeding year, we observed that hairy vetch had overwintered well, whereas barrel medic and black lentil had not, except when a few plants of barrel medic survived the winter of 1994-95. Results from this study indicate that legumes can be successfully interseeded into chile in the high-desert region of the southwestern United States without a significant decrease in chile yield.
\end{abstract}

Legumes can be useful in providing soil cover (Gilley et al., 1989; Hargrove and Frye, 1987; Power and Koerner, 1994; Schonbeck et al., 1993) and as green manures (Badaruddin and Meyer, 1990; Brown et al., 1993; Schonbeck et al., 1993; Singogo et al., 1991). In a Nebraska study (Gilley et al., 1989), planting date for several legumes significantly affected maximum surface cover and the number of days needed to achieve maximum cover. Studies by Schonbeck et al. (1993) indicated hairy vetch cover crops could potentially re-

Received for publication 2 May 1996. Accepted for publication 5 July 1996. A contribution of the New Mexico Agricultural Expt. Station, New Mexico State Univ., Las Cruces. We gratefully acknowledge the technical assistance of David J. Archuleta and Val S. Archuleta. Use of trade names does not imply endorsement of the products named nor criticism of similar ones not named. The cost of publishing this paper was defrayed in part by the payment of page charges. Under postal regulations, this paper therefore must be hereby marked advertisement solely to indicate this fact.

${ }^{1}$ Alcalde Sustainable Agriculture Science Center and Dept. of Agronomy and Horticulture.

${ }^{2}$ Department of Agronomy and Horticulture.

${ }^{3}$ Department of Experimental Statistics. duce $\mathrm{N}$ fertilizer inputs while maintaining production levels of Brassica vegetable crops in the northeastern United States.

These and other recent studies on legume cover crops have taken place under different climates, cropping systems, and/or soils than those found in the high-desert region of the southwestern United States. Many of the soils of this region are coarse-textured and of inherently low organic matter content and fertility. Legumes, because of their ability to fix $\mathrm{N}_{2}$, may be particularly useful as cover crops on these soils.

Relay intercropping has been defined as a form of multiple cropping in which a second crop is planted into the first crop when the first crop has reached its reproductive stage but before it is harvested (Andrews and Kassam, 1976). With the use of relay intercropping, two crops can be produced in 1 year in areas where the growing season is too short for sequential or double cropping. Relay intercropping may be a way to insert legume cover crops into rotations that include chile. However, very little information is available on chile-legume intercropping. In a study in Northern Victoria, Australia (Hulugalle and Willatt, 1987), a chile-soybean [Glycine $\max$ (L.) Merr.] intercrop exhibited a temporal stratification of water extraction over the growing season by intercropped chiles with low irrigation frequency. Monocropped chile yields were higher than with intercropping on a per-unit basis, and this was attributed to a higher plant population in the monocropped treatments.

To our knowledge, no research has been done on relay intercropping legume cover crops into chile. Developing such a system would be particularly beneficial for producers with small landholdings, such as those found in north-central New Mexico, who need to use land, sunlight, and other on-farm resources as efficiently as possible. Hairy vetch is commonly used as a winter cover and spring green manure crop and is known to grow well on sandy and sandy loam soils (Duke, 1981). 'Indianhead' black lentil has recently been developed for use as a green manure. It is frosthardy and the seed is relatively inexpensive compared to other grain legumes (Slinkard et al., 1987). Barrel medic and other annual Medicago species have been used extensively in southern Australia as pasture legumes in rotation with cereals to improve and maintain soil fertility (Puckridge and French, 1983). Many annual Medicago species are characterized as fast growers that produce large amounts of biomass (Diwan et al., 1994). The growth characteristics of black lentil and barrel medic may allow them to be sufficiently productive late in the season and thus make them suitable for relay intercropping into chile. In contrast, a legume that is too competitive or interseeded too early may have the potential to adversely affect chile yield.

We conducted an experiment in which three legumes were interseeded into chile at two dates in two growing seasons. The specific objectives were to determine the effect of time of legume interseeding on 1) yield of chile, and 2) late-season productivity and $\mathrm{N}$ yield of aboveground portions of legumes.

\section{Materials and Methods}

This experiment was conducted at Alcalde, N.M., on a Fruitland sandy loam [coarseloamy, mixed (calcareous), mesic Typic Torriorthent] during the 1993 and 1994 growing seasons. Soil organic matter content in the $0-15 \mathrm{~cm}$ depth was $\approx 0.37 \%$. Soil tests prior to trial establishment indicated the soil texture of the $0-15 \mathrm{~cm}$ depth to be sandy loam in the 1993 trial site and sand in the 1994 site. 'New Mexico 6-4' chile was planted on listed beds in rows $91 \mathrm{~cm}$ apart on 14 May 1993 and 9 May 1994 with a two-row planter. When plants were $\approx 10-13 \mathrm{~cm}(\approx 8.5$ weeks after planting $)$ they were thinned to two plants per hill and 30 $\mathrm{cm}$ between hills. Subplots were three rows wide and $6 \mathrm{~m}$ long. Weeds were controlled by a row-crop cultivator and hand weeding. All plots were furrow-irrigated as needed during the season. The average date of the first fall temperature of $-1{ }^{\circ} \mathrm{C}$ during 1985-94 at the study site is 9 Oct. The first fall temperature of $-1{ }^{\circ} \mathrm{C}$ or lower occurred on 20 Oct. 1993 and 9 Oct. 1994. The first fall temperature of $-2{ }^{\circ} \mathrm{C}$ or lower occurred on 20 Oct. 1993 and 10 Oct. 1994. 
Fertilization was based on general guidelines for chile in north-central New Mexico (Matta and Cotter, 1993; Trujillo and Gledhill, 1971). Because of the coarse soil and use of furrow irrigation, the fertilizer was split into two sidedressings, with 4-5 weeks between applications. The first occurred when the plants were about $3-7 \mathrm{~cm}$ tall and consisted of $\mathrm{P}$ at 13 $\mathrm{kg} \cdot \mathrm{ha}^{-1}$. The second occurred when the plants were about $15-25 \mathrm{~cm}$ tall and consisted of $\mathrm{N}$, $\mathrm{P}$, and $\mathrm{S}$ at 34,18 , and $29 \mathrm{~kg} \cdot \mathrm{ha}^{-1}$, respectively. The $\mathrm{P}$ in the first split was in the form of triple superphosphate $(20 \% \mathrm{P})$ in both years. Ammonium phosphate-sulfate $(16 \mathrm{~N}-8.7 \mathrm{P}-0 \mathrm{~K}-$ 14S) was used in the second split in 1993. In 1994, a mixture of urea, ammonium sulfate $(21 \mathrm{~N}-0 \mathrm{P}-0 \mathrm{~K}-24 \mathrm{~S})$, and triple superphosphate was used. Following all sidedressings, plots were cultivated with a two-row cultivator.

On 3 Aug. (early interseeding), when plants were $20-30 \mathrm{~cm}$ tall, and on 16 Aug. 1993 and 17 Aug. 1994 (late interseeding), when plants were $30-40 \mathrm{~cm}$ tall, 'Parabinga' barrel medic, 'Indianhead' black lentil, and 'Madison' hairy vetch were hand-broadcast into the standing chile. The plants were in the pod development stage during all interseedings. Seeding rates $\left(\mathrm{kg} \cdot \mathrm{ha}^{-1}\right)$ on a pure live seed basis were 22.4 for barrel medic, 56.0 for black lentil, and 44.8 for hairy vetch. Seed broadcast at the early date was incorporated with a row crop cultivator, and the seed broadcast at the late date was incorporated with hand rakes. All legume seed was inoculated with appropriate Rhizobium before sowing.

The design was a randomized complete block with a split-plot treatment structure and four replications. Main plots were time of legume interseeding, and subplots included legume species and a no-legume control.

Chile harvest dates analyzed were 17 and 28 Sept. and 11 Oct. 1993, and 12 Sept. and 5 Oct. 1994. Green mature pods were harvested from a 4.6-m length from the middle row of each subplot, and fresh mass was recorded. Data were lost from a harvest on 5 Aug. 1994; however, this loss does not interfere with realizing the objectives of the study because this harvest occurred at the onset of interseeding.

Table 1 . Aboveground dry matter and $\mathrm{N}$ yields of legume species following two interseeding dates in chile.

\begin{tabular}{|c|c|c|c|c|}
\hline \multirow[b]{4}{*}{ Legume } & \multicolumn{4}{|c|}{ Productivity criterion } \\
\hline & \multicolumn{4}{|c|}{ Interseeding date } \\
\hline & \multicolumn{2}{|c|}{1993} & \multicolumn{2}{|c|}{1994} \\
\hline & $\begin{array}{c}\text { Early } \\
\text { (3 Aug.) }\end{array}$ & $\begin{array}{c}\text { Late } \\
\text { (16 Aug.) }\end{array}$ & $\begin{array}{c}\text { Early } \\
\text { (3 Aug.) }\end{array}$ & $\begin{array}{c}\text { Late } \\
\text { (17 Aug.) }\end{array}$ \\
\hline & \multicolumn{4}{|c|}{ Dry mass $\left(k g \cdot h a^{-1}\right)$} \\
\hline Madison hairy vetch & 3370 a & $1470 \mathrm{a}$ & $1810 \mathrm{a}$ & $975 \mathrm{a}$ \\
\hline Parabinga barrel medic & $2330 \mathrm{a}$ & $2050 \mathrm{a}$ & $968 \mathrm{~b}$ & $618 \mathrm{a}$ \\
\hline Indianhead black lentil & $1900 \mathrm{a}$ & $1350 \mathrm{a}$ & $1330 \mathrm{ab}$ & $504 \mathrm{a}$ \\
\hline \multirow[t]{2}{*}{ Mean } & 2550 & 1620 & 1370 & 717 \\
\hline & \multicolumn{4}{|c|}{$N$ yield $\left(k g \cdot h a^{-1}\right)$} \\
\hline Madison hairy vetch & $136 \mathrm{a}$ & $58 \mathrm{a}$ & $56 \mathrm{a}$ & $28 \mathrm{a}$ \\
\hline Parabinga barrel medic & $82 \mathrm{a}$ & $77 \mathrm{a}$ & $30 \mathrm{~b}$ & $20 \mathrm{a}$ \\
\hline Indianhead black lentil & $67 \mathrm{a}$ & $52 \mathrm{a}$ & $38 \mathrm{ab}$ & $17 \mathrm{a}$ \\
\hline Mean & 96 & 62 & 41 & 22 \\
\hline
\end{tabular}

Mean separation within columns by Duncan's multiple range test at $P \leq 0.05$. Means are weighted because of unequal sample size.

Legumes were harvested on 8 Nov. 1993 and 15 Nov. 1994. Aboveground yields were measured by harvesting a $0.21-\mathrm{m}^{2}$ area from each subplot. The placement of the square quadrats was such that a representative crosssection of the furrow-bed continuum was obtained in each sample. Samples were ovendried at $65^{\circ} \mathrm{C}$ for $48 \mathrm{~h}$ and weighed. Samples were ground to pass a 1-mm screen, digested, and analyzed colorimetrically (sodium salicylate-sodium hypochlorite) for total Kjeldahl N using an autoanalyzer (Technicon, 1974). Nitrogen yield was obtained by multiplying the dry-matter yield by the $\mathrm{N}$ concentration for each legume.

Analysis of variance was performed using the General Linear Models procedure (SAS Institute, 1992). Chile yield data were analyzed separately for each year because of unequal number and spacing of harvests in 1993 compared with 1994. A single degree of freedom contrast was used to compare the means of the legume treatments with the no-legume controls in terms of chile yield. The legume yield data were also analyzed separately for each year because variance estimates indicated heterogeneous variances. An F test was used to verify this conclusion.

\section{Results and Discussion}

Chile. In a system of relay intercropping a legume cover crop into chile, most chile growers would likely consider the chile crop to be the primary, or most valuable, crop. It is thus important that the relay intercropped legume not detract from chile yield. Under the conditions of our study, neither legume interseeding time nor legume species significantly $(P>$ $0.05)$ affected September-October cumulative chile yield in either year. Chile yield averaged across legume treatments was similar $(P>$ $0.05)$ to chile yield averaged across the nolegume controls in either year. Total chile yield during these months averaged $4830 \mathrm{~kg} \cdot \mathrm{ha}^{-1}$ in 1993 and $3330 \mathrm{~kg} \cdot \mathrm{ha}^{-1}$ in 1994.

Legumes. The legume $\times$ interseeding time interaction for legume dry-matter and $\mathrm{N}$ yields was not significant in either year $(P>0.05)$. Early interseeded legume dry matter yields

HortScience, Vol. 31(7), December 1996 were about $57 \%$ and $91 \%$ higher than yields of late interseeded legumes in $1993(P=0.051)$ and $1994(P=0.053)$, respectively (Table 1$)$. Early interseeded legumes also had $55 \%$ and $86 \%$ higher $\mathrm{N}$ content than late interseeded legumes in 1993 and 1994, respectively $(P \leq$ $0.05)$ (Table 1). When interseeding is done in early to mid August, only a 2-week difference between interseeding dates can result in a relatively great difference in fall legume growth.

The only statistically significant $(P \leq 0.05)$ difference among legumes was for the early interseeding in 1994 (Table 1) when hairy vetch dry-matter and $\mathrm{N}$ yields were significantly higher than were those of barrel medic. In a legume interseeding study with sweet corn (Zea mays L.), black lentil dry-matter and $\mathrm{N}$ yields generally were significantly lower than those of both hairy vetch and barrel medic (Guldan et al., 1996).

Hairy vetch overwintered well at this site, whereas barrel medic and black lentil did not, except when a few plants of barrel medic survived the winter of 1994-95. Choosing among these legume cover crops would depend largely on the intended use of the field in the following season. Where overwintering is not desired, for example, when the following year's crop is direct-seeded early in the spring, black lentil or barrel medic may be suitable. In contrast, a late-spring transplanted crop the following year could benefit from the spring growth of the hairy vetch incorporated as a green manure (Singogo et al., 1996) or used as a surface mulch (Abdul-Baki et al., 1996). The spring growth of hairy vetch has also been used for spring grazing (Hoveland et al., 1960).

The results of this study indicate that legumes can be successfully interseeded into chile in the high-desert region of the southwestern United States without a significant decrease in chile yield. Additional research with other chile pepper types as well as under diverse soil and/or climatic conditions is warranted.

\section{Literature Cited}

Abdul-Baki, A.A., J.R. Teasdale, R. Korcak, D.J. Chitwood, and R.N. Huettel. 1996. Fresh-market tomato production in a low-input alternative system using cover-crop mulch. HortScience 31:65-69.

Andrews, D.J. and A.H. Kassam. 1976. The importance of multiple cropping in increasing world food supplies, p. 1-10. In: R.I. Papendick, P.A. Sanchez, and G.B. Triplett (eds.). Multiple cropping. Amer. Soc. Agron., Madison, Wis. Spec. Publ. 27.

Badaruddin, M. and D.W. Meyer. 1990. Greenmanure legume effects on soil nitrogen, grain yield, and nitrogen nutrition of wheat. Crop Sci. 30:819-825.

Brown, R.E., G.E. Varvel, and C.A. Shapiro. 1993. Residual effects of interseeded hairy vetch on soil nitrate-nitrogen levels. Soil Sci. Soc. Amer. J. 57:121-124.

Diwan, N., G.R. Bauchan, and M.S. McIntosh. 1994. A core collection for the United States annual Medicago germplasm collection. Crop Sci. 34:279-285.

Duke, J.A. 1981. Handbook of legumes of world 
economic importance. Plenum Press, New York.

Gilley, J.E., J.F. Power, P.J. Reznicek, and S.C. Finkner. 1989. Surface cover provided by selected legumes. Applied Eng. in Agr. 5:379385.

Guldan, S.J., C.A. Martin, J. Cueto-Wong, and R.L. Steiner. 1996. Dry matter and nitrogen yields of legumes interseeded into sweet corn. HortScience 31:206-208.

Hargrove, W.L. and W.W. Frye. 1987. The need for legume cover crops in conservation tillage production, p. 1-5. In: J.F. Power (ed.). The role of legumes in conservation tillage systems. Proc. Soil Conservation Soc. of Amer. Natl. Conf., Athens, Ga., 27-29 Apr. 1987.

Hoveland, C.S., W.B. Anthony, and E.L. Mayton. 1960. Coastal-vetch-crimson good for cows and calves. Ala. Agr. Expt. Sta. Highlights Agr. Res. 7(3):7.

Hulugalle, N.R. and S.T. Willatt. 1987. Seasonal variation in the water uptake and leaf water potential of intercropped and monocropped chillies. Expt. Agric. 23:273-282.

Matta, F.B. and D.J. Cotter. 1993. Chile production in north-central New Mexico. New Mexico State Univ. Coop. Ext. Serv. Guide H-225.

Power, J.F. and P.T. Koerner. 1994. Cover crop production for several planting and harvest dates in eastern Nebraska. Agron. J. 86:1092-1097.

Puckridge, D.W. and R.J. French. 1983. The annual legume pasture in cereal-ley farming systems of southern Australia: A review. Agr., Ecosystems and Environ. 9:229-267.

SAS Institute. 1992. SAS user's guide. Ver. 6. SAS Institute, Cary, N.C.

Schonbeck, M., S. Herbert, R. DeGregorio, F Mangan, K. Guillard, E. Sideman, J. Herbst, and R. Jaye. 1993. Cover cropping systems for Brassicas in the Northeastern United States: 1. Cover crop and vegetable yields, nutrients and soil conditions. J. Sustainable Agr. 3(3/4):105-132. Singogo, W., W.J. Lamont, Jr., and C.W. Marr.
1991. Legumes alone and in combination with manure as fertilizers in an intensive muskmelon production system. HortScience 26:1431.

Singogo, W., W.J. Lamont, Jr., and C.W. Marr. 1996. Fall-planted cover crops support good yields of muskmelons. HortScience 31:62-64.

Slinkard, A.E., V.O. Biederbeck, L. Bailey, P. Olson, W. Rice, and L. Townley-Smith. 1987. Annual legumes as a fallow substitute in the northern Great Plains of Canada, p. 6-7. In: J.F. Power (ed.). The role of legumes in conservation tillage systems. Proc. Soil Conservation Soc. of Amer. Natl. Conf., Athens, Ga., 27-29 Apr. 1987.

Technicon Instruments Corporation. 1974. Ammoniacal nitrogen/BD acid digests. Industrial method no. 321-74A. Technicon Instruments Corp., Tarrytown, N.Y.

Trujillo P. and V.H. Gledhill. 1971. Chile fertilizer trials at the Espanola Valley Branch Station. New Mexico State Univ. Agr. Expt. Sta. Res. Bul. 575. 